\title{
Towards Integrated Team Practice: A Case of Malaysian Industrialised Building System (IBS) Construction Projects
}

\author{
Mohd Nasrun Mohd Nawi ${ }^{1}$, Santhisegaran Nadarajan ${ }^{2}$, Mohd Faizal Omar ${ }^{3}$, Mohd Azian Zaidi ${ }^{4}$, \\ Mohd Fadzil Mat Yasin ${ }^{5}$ \\ ${ }^{1,2}$ School of Technology Management and Logistics, Universiti Utara Malaysia, 06010 Sintok, Kedah, \\ Malaysia \\ ${ }^{3}$ Department of Decision Science, School of Quantitative Sciences,College of Arts and Sciences, \\ Universiti Utara Malaysia, 06010 Sintok, Kedah, Malaysia \\ ${ }^{4,5}$ Senior Lecturer, Faculty of Architecture, Planning and Surveying,Universiti Teknologi MARA \\ Perak,Seri Iskandar, 32610 Perak
}

\begin{abstract}
Problems associated with fragmentation in the traditional construction process, such as isolation of professionals, lack of co-ordination between design and construction, and the sequential manner of its processes, has impacted on construction performance leading to a lack of integration, wastage, low productivity and efficiency. Integrated team practice is perceived as paramount. Unfortunately, there has a limitation of study focus on the dimension of fully integrated team especially for Malaysian Industrialised Building System (IBS) projects. Accordingly, this research paper explores and identifies the dimension of fully integrated team from the traditional approach and conduct a validation process for implementing it in Malaysian IBS projects. The research presented uses interviews case study to obtain qualitative data. It was found that the dimension of fully integrated team from the traditional construction process could apply to the Malaysian IBS projects. Suggestions on how an integrated team practice in IBS design and construction process in order to minimise the fragmentation gaps will be concluded.
\end{abstract}

\section{Introduction}

The importance of the construction industry to national social-economies is not a subject for debate. The construction plays a major role as a key indicator and determine of domestic economy and capital income of a country [24, 25]. In Malaysia, the construction sector is divided into four broad categories: office; retail; residential and infrastructure [31]. The sector needs to be managed with an alignment process and must be complied with the environmental policy for the protection of future generations which is called as sustainable. Sustainable construction is a subset to the sustainable development which described the responsibility of the construction industry to attain sustainability [30]. Sustainable development is one of Malaysia's sustainable strategies was developed [26, 28]. Malaysia is witnessing rapid development, the construction industry has been encouraged to shift from the conventional practice towards industrialised approach as part of the sustainable concept. Although Industrialised Building System (IBS) has a solution towards improving constructions sustainability however implementation of this system faced a lot of barriers like lack of integration among stakeholders during design stage in project life cycle. Therefore, 'integrated project team' has been identified as one of the appropriate approaches that can provide an effective framework for integrating 
in order to overcome that problem [17, 27, 29]. An integrated delivery team is a highly effective to brings together various skills and knowledge, and removes the traditional barriers towards an effective and efficiency delivery of the project $[4,33]$. For example, involvement of IBS's specialty contractors or manufacturers early in the design process will help design professionals to see how a contractor will implement the design. This strategy is indirectly hinders the result in scheduling problems, delays and disputes during the construction process, and, hence, harm the overall project performance [4, 18, 32]. Based on the literature review from the previous studies [1, 3, 6, 8, 9, 10, 14, 21, 23] it has been identified that the delivery team on a construction project can be described as 'fully integrated' when it:

- has a single focus and objectives for the project

- operates without boundaries among the various organization members and work towards mutually beneficial outcomes

- shares information freely among its members such that access is not restricted to specific professions and organisational units within the team

- has a new identity and is co-located, usually in a given common space

- operates in an atmosphere where relationships are equitable, offers its members equal opportunities to contribute to the delivery process and all members are respected

- has a "no blame", culture

Due to validity and practicality of data, [36] warned that secondary data has the disadvantage of becoming out-of-date, as well as not being appropriate for the precise needs of a particular research problem. [37] also claimed that secondary data by itself cannot meet the specific needs of particular situations, problems or settings, and it is essential to obtain primary data to overcome this shortcoming. In view of that, this type of research is generated to gather the primary data and also to validate all the dimension that have been identified as general either it could be applied for Malaysian IBS industry or not.

\section{Methodology}

The data was obtained from a case study organized by researchers. A number of interviews with three officers from different job functions (top level of management, operational, and technical department) were conducted in validating the dimension of integrated project team in construction. The main selection criteria for inviting the survey participants to the interview session is to have at least 5 years of working experience in IBS related projects. Case study is a strategy for doing research which involves an empirical investigation of a particular contemporary phenomenon within its real life context using multiple sources of evidence [34]. Many researcher i.e. [17, 35] clearly agreed that interview is one of the establish tool or technique for qualitative data collection especially for the research that involve case study as a research design.

For the purpose of this study, the interviews were conducted two times at two difference venues. The first interview was conducted with managing director and design engineer of the company in the headquarter office meeting room. The second interviews were conducted with operation manager in the site office meeting room. Due to the need to maintain confidentiality and anonymity, the interviewees' names are not revealed. Therefore, prefix codes listed-in Table 1 were used. Both of the interviews session used structured and semi structured questionnaires focus on validation of dimension of fully integrated team delivery in the Malaysian IBS project. The results of the interviews are presented in Table 2 below.

Table 1: Interview quotation code prefixes details

\begin{tabular}{|c|c|}
\hline Interviewee ID & Code Prefix \\
\hline Managing Director & RCS-01-01 \\
\hline Operation Manager & RCS-01-02 \\
\hline Senior Design Engineer & RCS-01-03 \\
\hline
\end{tabular}




\section{Result and Discussion}

Based on the findings from the case study, it was confirmed that the entire dimension obtained from the literature review are necessary to be applied in IBS projects in order to achieve a fully integrated team delivery. The findings below shows all the recommendations discussed during the case study interview

Table 2: Summary of recommendations from the Validation Case Study

\begin{tabular}{|c|c|}
\hline Dimension & Recommendation \\
\hline $\begin{array}{l}\text { Single focus and } \\
\text { objectives }\end{array}$ & $\begin{array}{l}\text { Each of the team members is responsible for the progress and performance of the project } \\
\text { from beginning until the completed of the project. They must have a feel of 'sense of } \\
\text { ownership' when do the job thus putting extra effort that beyond their routine of duty. } \\
\text { Most of the respondents agreed that this factor is essential for the successful of } \\
\text { integrated design team delivery. } \\
\text { 'In the beginning of a project, we always practice that all the project team members are } \\
\text { understand on their duty and responsibility of the project to avoid duplicate of job and } \\
\text { wastage' - Managing Director } \\
\text { 'In the current practice, we need to update the progress of work through the monthly } \\
\text { meeting with design manager in order to avoid something bad happened in the future'- } \\
\text { Senior Design Engineer } \\
\text { 'As a leader, we make sure that we create a single goal of direction especially to fulfil } \\
\text { the client requirement. At the same time, we make sure all members are clearly } \\
\text { understood the project's vision and mission' in the delivery of project - Managing } \\
\text { Director }\end{array}$ \\
\hline $\begin{array}{l}\text { Operates without } \\
\text { boundaries }\end{array}$ & $\begin{array}{l}\text { Operational in this study refers to a process or series of actions such as has an interaction } \\
\text { space, co-located of team, non operational boundary, collaborative, and teamwork } \\
\text { supportive of climate. According to respondents, these entire components are very } \\
\text { important thus indirectly will improve team culture and attitude among professional } \\
\text { disciplines towards successful integrated team. } \\
\text { 'We always think about transportation issues during the design phase to avoid problems } \\
\text { happened during the transportation or delivery process. All the information is discussed } \\
\text { with design team during consultant meeting or walk in to consultant firm' - Operation } \\
\text { Manager } \\
\text { 'Normally, we spend around } 3 \text { month for design process. At the same time, the } \\
\text { substructure work was started to reduce the time of constructions. However, the time } \\
\text { period of design stage should be longer than in the current practice to produce best } \\
\text { quality of design'-Senior Design Engineer }\end{array}$ \\
\hline $\begin{array}{l}\text { Shares information } \\
\text { freely }\end{array}$ & $\begin{array}{l}\text { The respondents mostly agreed that technology plays as a medium or appropriate } \\
\text { mechanism to co-ordinate activity, enhance interaction and knowledge sharing within a } \\
\text { project team. In this project, technology is needed to support team communication due to } \\
\text { temporal and departmental constraints. } \\
\text { 'IT is an important tool to visualize drawing and improve communication during IBS } \\
\text { design process. Currently we move to } 3 D \text { instead of } 2 D \text { drawings for designers and } \\
\text { manufacturers having better view and understanding of detail IBS components' - } \\
\text { Managing Director } \\
\text { 'Technology visualization is the key to coordinate and enhance interaction during the } \\
\text { design and manufacture stage. It requires avoiding any mistake and failure during } \\
\text { design process particularly in the technical drawing'-Operation Manager } \\
\text { 'AutoCAD, Esteem, Staad Pro 2005, Orion and Tekla are among the software that we } \\
\text { always use during the IBS design processes'-Senior Design Engineer }\end{array}$ \\
\hline $\begin{array}{l}\text { New identity and } \\
\text { co-location }\end{array}$ & $\begin{array}{l}\text { The integrated design team delivery was set up to maintain central control of the various } \\
\text { organizations. This team is usually given a common space operates in an atmosphere } \\
\text { where relationships are equitable and members are respected. This approach brought all } \\
\text { the functional expertise that is required for the project together to act within a single } \\
\text { entity with working collaboratively rather than individuals. Therefore all the team } \\
\text { members could able to respond to change over the duration of the project. The }\end{array}$ \\
\hline
\end{tabular}




\begin{tabular}{|c|c|}
\hline & $\begin{array}{l}\text { interviews agreed that this approach is significantly affected for improving integration } \\
\text { team practice. } \\
\text { 'The current team structure makes it easier to manage the various consultants and other } \\
\text { parties who involved in the design of the project in effectively. It's also easier to ensure } \\
\text { that all issues related to design such as manufacturability and constructability are dealt } \\
\text { earlier in the beginning of project' - Managing Director } \\
\text { 'Flexibility and balance of process between factory and site is critical. For example, } \\
\text { when works at site are stopped, casting at factory shall also stop. Therefore, the concept } \\
\text { of early involvement and fully utilizes of collective skills and expertise from the both } \\
\text { sides during the design stage is very important especially to prevent double handling } \\
\text { and problems with storage'-Operation Manager } \\
\text { 'We will make sure that all of our design engineers are qualified, recognize and } \\
\text { registered with the professional body such as board of engineer Malaysia etc' in order } \\
\text { to avoid any bad thing happened in future - Managing Director } \\
\text { 'I think the production and construction issues must be incorporated earlier during the } \\
\text { design stage in order to ensure smooth project sequences and error-free of construction' } \\
\text { - Senior Design Manager }\end{array}$ \\
\hline $\begin{array}{l}\text { No 'blame each } \\
\text { other' culture }\end{array}$ & $\begin{array}{l}\text { Transparency in this study refers to the commitment of open, frequent and genuine } \\
\text { communication among team members in a construction project. Respondents agreed that } \\
\text { this transparency communication will create a good collaborative working environment } \\
\text { such as resolution of disagreement without confrontation among team's members. } \\
\text { 'We try our best to create the necessary environment for all members of the delivery } \\
\text { team to know each other through social functions and family activity' - Managing } \\
\text { Director } \\
\text { 'Normally, we will use the weekly meeting to solve our problem. Meeting is an } \\
\text { appropriate medium for everybody to declare their problem and it is very effective to } \\
\text { avoid confrontation or miscommunication among members at site' - Operation } \\
\text { Manager } \\
\text { 'We have been working on this project for long time and I do believe the relationships } \\
\text { that exist among us are good at all. Every member is respect among each other and } \\
\text { there has no blame culture in our team'-Senior Design Engineer }\end{array}$ \\
\hline
\end{tabular}

Based on the findings identified from the case study, all the dimension factors are significance to be implemented in the Malaysian IBS projects except work in relationship environment. On the other hand, the respondents also suggested that some others dimension also need to be added in order to enhance the efficiency of integrated team project delivery. For example, the respondent recommended that personal attitude, policy and leadership are among the extra dimension should be considered for a team to archive fully integrated team in Malaysian IBS projects. All the recommendations are highlighted as below:

\section{- Excellent personal working attitude}

This factor that represents an individual's degree of like or dislike for work has been identified critical by all the respondents in order to achieve fully integrated team in construction project. All the respondents agreed that "doing what you love" in routine work can create a powerful motivator of group performance including commitment, continuity and positive self improvement.

'My style is so simple to train and approach our staff. Firstly, know their expertise; give the appropriate job and allocate a flexibility of time to complete the task. Sure they will happy and enjoy with their current job' - Managing Director

'Personally I think 'openness of thinking' is the key for the team to be excellent and work in collaborative manner' - Operation Manager

'A few of our engineers are fresh but they are very committed and willing to learn that something new especially related to technology or software. As a senior staff, we are also happy to teach and share our knowledge and skill together' - Senior Design Engineer 


\section{- Policy}

Respondent consents that the government policy has been noted as one of the key influences in promoting a new technique or products in the Malaysian construction industry. According to them, this is simply because the government is one of the biggest clients for the IBS construction project in Malaysia. This policy typically will affect the delivery of a construction project either in term of process or team structure.

'Our vision company is always aligning with the government policy in order to gain some beneficiary of practice such reduction of levy, tax etc.'-Operation Manager

\section{- Leadership}

Management of leadership has been validated by the respondents as critical factor to ensure the vision and strategy of a team is communicated effectively to all members. The supportive from top management and all senior managers in term of sponsorship, training, commitment and empowerment are essential towards successful integrated team delivery. The competency of team members is part of the fundamental key success to IBS integrated design team.

'Training scheme is part of the continuous improvement process in our organization of project. This process is the fundamental success for integrated design team through the development of staff competency'-Managing Director

'Company provides continuous education and training activities such as hands-on and on-the-job labour training, particularly in technical part such as installation and jointing panel systems' Operation Manager

\section{Conclusion}

Even though, a list of dimension for fully integrated teams have been identified to become the core elements for the development of a framework for effective integrated design team delivery in Malaysian IBS projects, unfortunately, the findings of the dimension are based on the traditional construction process as a general. The specific dimensions of fully integrated team that relate to the IBS Malaysian construction industry are still limited. Therefore, this research conduct a validation process through a case study interviews with Malaysian industry players in order to transform the lesson learns from the traditional practice to IBS. The findings from this study shows almost all the dimensions identified from the previous studies are the significance to be applied towards fully integrated team except the factor of 'work in relationship environment.' For the recommendation of future study improvement, it needs a few more similar studies in order to support the dimension as a core element for the developing a framework for effective integrated design team delivery in Malaysian IBS projects.

\section{References}

1. Anumba, C.J. Baugh, C.A., Khalfan, M.M.A., 2002. Organization Structure to Support Concurrent Engineering to Construction, Industrial Management and Data Systems, 102/5, pp. 260-270.

2. Austin, S.A., Baldwin, A.N., Steele, J.L., 2002. Improving building design through integrated planning and control, Engineering, Construction and Architectural Management, Vol. 9 No. 3, pp. 349-58.

3. Baiden, B.K., Price, A.D.F.; and Dainty, A.J.R., 2003. Looking beyond processes: Human factors in team integration, In: D. J. Greenwood, ed.,ARCOM, Brighton. 
4. Baiden, B.K., Price, A.D.F.; and Dainty, A.R.J., 2006. The extent of team integration within construction projects, International Journal of Project Management, 24 (1), 13-23.

5. Bohari, A.A.M., Mahat, N. and Kipli, K., 2012. Industrialised Building System (IBS) in Sarawak Construction Industry. International Conference on Innovation, Management and Technology Research (ICIMTR2012), Malacca, Malaysia.

6. Bromley, S., Worthington, J., and Robinson, C., 2003. The impact of integrated Teams on the design process, London: Construction Productivity Network.

7. Buildoffsite, 2008. Your guide to specifying Modular Buildings Maximizing value and minimizing risk Buildoffsite \& BAA, London.

8. Cornick, T. and Mather, J., 1999. Construction project teams: making them work profitably. London: Thomas Telford.

9. Dainty, A.R.J., Briscoe, G.H.; and Millett, S.J., 2001. Subcontractor perspectives on supply chain alliances. Construction Management and Economics, 19 (8), 841-848.

10. Evbuomwan, N.F.O.; and Anumba, C.J., 1998. An integrated framework for concurrent life-cycle design and construction, Advances in Engineering Software, 29 (7-9), 587-597.

11. Gibbs, A., 1997. Focus Groups. Social research update, Issue 19 (C) University of Surrey, UK.

12. IBS Roadmap 2003-2010, 2003. Construction Industry Development Board (CIDB), Kuala Lumpur.

13. Kamar, K.A.M., Hamid Z.A. and Dzulkalnine N., 2012. Industrialised Building System (IBS) Construction: Measuring the Perception of Contractors in Malaysia. IEEE Business, Engineering and Industrial Application Colloquium (BEIAC).

14. Kamara, J.M., Anumba, C.J.; and Evbuomwan, N.F.O., 2000. Establishing and processing client requirements - a key aspect of concurrent engineering in construction. Construction Engineering and Architectural Management, 7 (1),15-28.

15. Kitzinger, J., 1995. Introducing focus groups, British Medical Journal, 311: 299-302.

16. Love, P.E.D., Irani, Z., Edwards, D.J., 2004. A seamless supply chain management model for construction, Supply Chain Management: An International Journal, Vol. 9 No.1, pp.43-56.

17. Nawi, M.N.M., Lee, A., K.A.M. Kamar and Hamid, Z.A., 2012 Critical Success Factors for Improving Team Integration in IBS Construction Projects: The Malaysian Case. Malaysia Construction Research Journal (MCRJ), Vol. 10 (1).

18. Nawi, M.N.M., Lee, A., K.A.M. Kamar and Hamid, Z.A., 2011. A Critical Literature Review on The Concept of Team Integration in Industrialised Building System (IBS). Malaysia Construction Research Journal (MCRJ), Vol. 9 (1).

19. Pan, W., Gibb, A. G. F. and Dainty, A. R. J., 2005. Offsite Modern Methods of Construction in Housebuilding Perspectives and Practices of Leading UK Housebuilders in Buildoffsite Report 2005 Loughborough University, pp. 14

20. Powell, R.A. and Single H.M., 1996. Focus groups. International Journal of Quality in Health Care 8(5): 499- 504.

21. Strategic Forum for Construction, 2003. The integration toolkit guide: Integrated project team, London: Strategic Forum for Construction.

22. Thanoon, W.A.M., Peng, L.W., Kadir, M.R.A., Jaafar, M. S. and Salit, M. S., 2003. The Essential Characteristics of Industrialised Building System, Proceeding of International Conference Industrialized Building Systems,Kuala Lumpur, Malaysia.

23. Vyse, S., 2001. Fusion: a new approach to working, London: G1axoWelleome

24. Abu Bakar, A.H., A. Awang, M.Z. Yusof and A. Adamy, 2011. Strategies for Survival During Economic Downturn in Construction Industry. A survey on Construction Companies in Malaysia. World Applied Sciences Journal, 13 (9): 1967-1974.

25. Memon, H. A., Rahman, I.A., Aziz, A.A.A. and Abdullah, N.H., 2013. Using Structural Equation Modelling to Assess Effects of Construction Resource Related Factors on Cost Overrun, World Applied Sciences Journal, 21 (Mathematical Applications in Eng.): 06-15.

26. Zakiah, P., Che, M. C. O., Ahmad, M. A. and Azizi, M., 2011. Matrix Sustainable Strategies Compatibility Analysis of Malaysia's Sustainable Development Strategies in Three-Tier 
Development Plan System, World Applied Sciences Journal. 14 (Exploring Pathways to Sustainable Living in Malaysia: Solving the Current Environmental Issues): 22-30.

27. Vasanthi, R.P and Bakar, A.H.A., 2011, The Needs for Standardisation of Document Towards an Efficient Communication in Construction Industry, World Applied Sciences Journal. 14 (9): 1988-1995.

28. Onyeizu, E.N., and A. H. Abu Bakar, 2011. The Utilisation of Inustrialised Building System in Design Innovation in Construction Industry. World Applied Sciences Journal 15 (2): 205-213.

29. Akbar, W. Bhatti, Hussain N. and Iqbal, J., 2013, Leadership Role in Integrating Knowledge Management Enablers. World Applied Sciences Journal 26 (1): 55-60.

30. 30. Fazdliel Aswad Ibrahim, Mohd Wira Mohd Shafiei, Ilias Said and Radzi Ismail, 2013. Malaysian Housing Developers' Readiness in Green Homes Development. World Applied Sciences Journal, 30: 221-225.

31. Mirsaeedie L. 2012. Application of Industrialized Building Systems (IBS) in Rurall Settlements Towards Sustainability. World Applied Sciences Journal 16 (5): 729-733.

32. Nawi, M. N. M., Lee, A., Azman, M.N.A., and Kamar, K.A.M., 2014. Fragmentation Issue in Malaysian Industrialised Building System (IBS) Projects. Journal of Engineering Science \& Technology (JESTEC), Vol. 9 (1), 97-106.

33. Nawi, M.N. M., Lee, A.; and Nor, K.M., 2011. Barriers to Implementation of the Industrialised Building System (IBS) in Malaysia. The Built \& Human Environment Review, 4, 22-35.

34. Saunders, M., Lewis, P. and Thornhill, A., 2007. Research methods for business students. 4th ed. Harlow: Pearson Education Ltd.

35. Yin, R. K. (2009) Case Study Research: Design and Methods, 4th ed., California, London, SAGE.

36. Bell, J. (1991) Doing Your Research Project.3th ed. Buckingham, Open University Press.

37. Mohamad, I.M. (1999) The Application of Concurrent Engineering Philosophy to the Construction Industry. Thesis $\mathrm{PhD}$, Loughborough University. 